\title{
Determinants of, and reference equation for, exhaled nitric oxide in the Chinese population
}

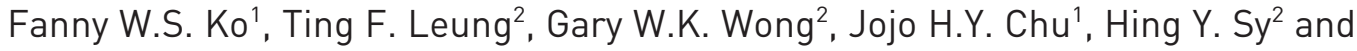 \\ David S.C. Hui ${ }^{1}$
}

Affiliations: 'Dept of Medicine and Therapeutics, The Chinese University of Hong Kong, Hong Kong, and ${ }^{2}$ Dept of Paediatrics, The Chinese University of Hong Kong, Hong Kong, China.

Correspondence: F.W.S. Ko, Dept of Medicine and Therapeutics, The Chinese University of Hong Kong, Prince of Wales Hospital, 30-32 Ngan Shing Street, Shatin, New Territories, Hong Kong, China. E-mail: fannykodcuhk.edu.hk

ABSTRACT Measurement of fractional exhaled nitric oxide concentration ( $F$ eNO) has been proposed as a useful biomarker for monitoring and management of airway diseases. Limited information is available regarding reference levels of $\mathrm{FeNO}$ levels in Chinese adults. This study aimed to investigate the reference equation and determinants of FeNO in Chinese adults.

1093 (577 males) healthy nonsmoking subjects aged 18-90 years were recruited. FeNO was measured online using a chemiluminescence analyser. Other assessments included spirometry, skin prick tests, total serum IgE levels and eosinophil count in peripheral blood.

The geometric mean FeNO was 32.6 (95\% reference interval (RI) 31.4-33.7) ppb for all subjects. FeNO values were higher in males than females (geometric mean (95\% RI) 38.3 (36.5-40.2) ppb versus 27.1 (25.828.5) ppb, $\mathrm{p}<0.0001)$, and in atopic than nonatopic subjects (34.6 (33.0-36.3) ppb versus 29.8 (28.331.4) $\mathrm{ppb}, \mathrm{p}<0.0001)$. FeNO correlated with age $\left(\mathrm{r}^{2}=0.23\right)$, height $\left(\mathrm{r}^{2}=0.20\right)$, IgE level $\left(\mathrm{r}^{2}=0.18\right)$ and percentage eosinophil count $\left(\mathrm{r}^{2}=0.18\right.$ ) (all $\mathrm{p}<0.0001$ ), but not with spirometric parameters. Based on multiple regression modelling, the reference equation of FeNO value was:

$\log \left(F_{\mathrm{eNO}}\right)=0.781+0.104(\mathrm{sex})+0.004($ age $)+0.084($ atopy $)+0.003$ (height in $\left.\mathrm{cm}\right)$, where for sex $1=$ male and $0=$ female, age is measured in years, for atopy $1=$ atopic and $0=$ nonatopic, and height is measured in $\mathrm{cm}$.

The FeNO of Chinese adults is higher than that of the Caucasian population, and is affected by age, sex, height and atopic status. This study provides useful references for the interpretation of FeNO.

-

@ERSpublications

Exhaled NO fraction in Chinese adults is higher than in Caucasians, and is affected by age, sex, height and atopy http://ow.ly/15mNR

\footnotetext{
Received: Aug 202012 | Accepted after revision: Nov 062012 | First published online: Nov 222012

Support statement: This study is supported by a Hong Kong Lung Foundation Research Grant and the Respiratory Research Fund of the Chinese University of Hong Kong.

Conflict of interest: None declared.

Copyright @ERS 2013
} 


\section{Introduction}

Noninvasive assessment of airway inflammation has been a popular research topic in recent years. Assessment of biomarkers in exhaled breath, such as fractional exhaled nitric oxide concentration ( FeNO) or biomolecules in the exhaled breath condensate, is entirely noninvasive and has great potential for serial monitoring of airway inflammation [1]. There is a growing body of literature on FeNO measurement. As FeNO measurement becomes more important and popular, the American Thoracic Society (ATS) and the European Respiratory Society (ERS) have published guidelines for the measurement of FeNO [2, 3]. FeNO was first demonstrated to be significantly elevated in subjects with asthma two decades ago [4]. Treatment of asthma with inhaled corticosteroids could reduce FeNO in asthmatics [5]. FeNO correlated with other markers of inflammation such as peripheral blood eosinophil count and eosinophil cationic protein level [6, 7]. Some studies have demonstrated that FeNO measurement might be useful for the diagnosis of asthma in adults $[8,9]$. FeNO measurement has also been investigated in the treatment algorithm for asthma. However, randomised controlled algorithm asthma control trials revealed equivocal benefits when adding FeNO measurement to the routine guideline management including spirometry $[1,10]$.

Correct interpretation of FeNO value is important when applying this tool for assessment of airway inflammation. Previous studies on reference values of FeNO in the general population were mainly limited to children [11-13]. There are limited data on the reference value of FeNO in the adult population [14-18], and there is very limited information on FeNO in a healthy, nonsmoking Chinese population. FeNO is a promising noninvasive marker for the assessment of airway inflammation, especially for asthma. Understanding FeNO in the normal population and factors that may affect its level can improve our understanding of the role of FeNO in the clinical management of respiratory diseases. The aim of this study was to establish a reference equation of FeNO in a large healthy Chinese adult population.

\section{Methods}

\section{Subject recruitment}

This was a cross-sectional observational study in which FeNO was measured in healthy Chinese adults in Hong Kong. Subjects were recruited by advertisements posted at the Chinese University of Hong Kong, Prince of Wales Hospital (Hong Kong, China) and newspapers. Subjects aged between 18 and 90 years who had expressed interest in this study were stratified into different age groups and randomly selected to participate in the study so that each age group of both sexes would have a similar number of subjects. All subjects were not current smokers. Previous smokers must have stopped smoking for at least 1 year with a smoking history of $<10$ pack-years. Subjects with a history of chronic respiratory diseases like asthma, chronic obstructive pulmonary disease, bronchiectasis, previous lung surgeries, chronic cough and sputum and wheeze over the past year were excluded. The study was approved by the ethics committee of the Chinese University of Hong Kong (approval number: CRE-2006.438) and informed consent was obtained from each subject.

\section{FeNO measurement}

FeNO was measured in the morning (between 09:00 h and 11:00 h) before spirometry. FeNO was measured online using a chemiluminescence analyser (NOA 280i; Sievers Instruments, Boulder, CO, USA) according to ATS/ERS recommendations [2]. Subjects were in the sitting position (with no nose clip); they exhaled to residual volume, inserted a mouth piece, inhaled to total lung capacity, and then exhaled for $10 \mathrm{~s}$ at a constant flow rate of $50 \mathrm{~mL} \cdot \mathrm{s}^{-1}$. The measurement was repeated until three FeNO values varied $<10 \%$ or two values varied $<5 \%$. The mean FeNO (in ppb) was then recorded. All subjects had to refrain from strenuous physical activity or exercise for $\geqslant 30 \mathrm{~min}$ prior to $\mathrm{FeNO}$ measurement. In addition, subjects avoided eating for $1 \mathrm{~h}$ and caffeine ingestion for $6 \mathrm{~h}$ before the test. Subjects were not tested within 4 weeks of an upper or lower respiratory tract infection.

\section{Spirometry}

Spirometry (pre- and post-bronchodilator) was performed using the MicroLab 3300 spirometer (CareFusion, Basingstoke, UK), according to the ATS standards [19].

\section{Skin prick test}

Allergen skin prick test was performed on the volar aspect of forearm using a panel of eight common aeroallergens according to standard methods [20]. A wheal size $3 \mathrm{~mm}$ larger than negative control $15 \mathrm{~min}$ after skin prick was considered a positive test. Allergens including Dermatophagoides pteronyssinus and $D$. farinae, house dust, cockroach, Cladosporidium, Bermuda grass, cat fur and dog hair (ALK-Albelló, Hørsholm, Denmark) were used. 
Blood test

Peripheral blood was taken for measurement of eosinophil count and total IgE level.

\section{Statistical analysis}

Data were categorised and analysed using the Statistical Package for Social Sciences (SPSS) for Windows release 17.0 (SPSS Inc., Chicago, IL, USA). FeNO values were log-transformed before analysis. FeNO is presented as geometric mean and 95\% reference interval (RI) (RI was calculated by exponentiating the reference limit obtained from the log-transformed data) and median with interquartile range, as appropriate. The associations between FeNO and anthropometric measurements, spirometric variables and atopic status were assessed by multivariate linear regression and Spearman correlations. The reference equation was computed by multiple linear regression modelling. From the predictors selected a priori, the variables for the final regression model were chosen using backward stepwise regression analysis. The upper 95\% cut-off limits were calculated from the regression model based on the whole population, taking into account age, sex, height and atopic status of the subjects using mid-class values in the group. All comparisons were made two-sided, and p-values $<0.05$ were considered significant.

\section{Results}

In total 1113 subjects were recruited for this study. Among these subjects, $1093(98.2 \%)$ were able to perform satisfactory FeNO measurement (i.e. able to maintain the flow rate or produce reproducible results) and were included in the final analyses. Among those 20 subjects (six males and 14 females) who could not perform satisfactory FeNO measurement, nine (45\%) and four (20\%) were aged $>60$ and $>70$ years, respectively. In the 1093 subjects with satisfactory FeNO measurement, 24 (2.2\%) had bronchodilator reversibility in the spirometry examination, and only two subjects $(0.2 \%)$ had post-bronchodilator forced expiratory volume in $1 \mathrm{~s}<80 \%$ predicted normal. The demographic characteristics of the subjects are shown in table 1.

The geometric mean FeNO was 32.6 (95\% RI 31.4-33.7) ppb. The range of FeNO was 4.2-315 ppb. FeNO value was higher in males than females (geometric mean (95\% RI) 38.3 (36.5-40.2) ppb versus 27.1 (25.828.5) ppb, $\mathrm{p}<0.0001)$ and higher among atopic when compared with nonatopic subjects (34.6 (33.036.3) ppb versus $29.8(28.3-31.4) \mathrm{ppb}, \mathrm{p}<0.0001)$. FeNO correlated with age $\left(\mathrm{r}^{2}=0.23, \mathrm{p}<0.0001\right)$, height $\left(\mathrm{r}^{2}=0.20, \mathrm{p}<0.0001\right)$, IgE level $\left(\mathrm{r}^{2}=0.18, \mathrm{p}<0.0001\right)$ and percentage eosinophil count $\left(\mathrm{r}^{2}=0.18, \mathrm{p}<0.0001\right)$. However, FeNO had no correlation with spirometric parameters. We entered parameters that had significant correlations with $\mathrm{FeNO}$ into a multivariate linear regression model, and found that sex, age, height, atopic status, serum IgE level and blood percentage eosinophil count were independently associated with $\mathrm{FeNO}$ value (table 2).

By putting the demographic parameters, including age, sex and height, together with atopic status by skin prick test, into a multiple linear regression modelling, the reference equation of FeNO in our Chinese adults is as follows:

$\log \left(F_{\mathrm{eNO}}\right)=0.781+0.104($ sex $)+0.004($ age $)+0.084($ atopy $)+0.003$ (height $)$

where for sex $1=$ male and $0=$ female, age is measured in years, for atopy $1=$ atopic and $0=$ nonatopic and height is measured in $\mathrm{cm}$. The intercept value was $0.78, \mathrm{r}^{2}$ was 0.144 and residual SD was 0.24 .

Using this reference equation, we calculated the upper 95\% cut-off limits for FeNO, according to height and age (using the mid-class values). The data are presented in table 3 and the corresponding graphic presentation is shown in figure 1 for both atopic and nonatopic subjects.

\section{Discussion}

This has been the first large scale study assessing the FeNO value in the Chinese adult population. We have developed a reference equation for prediction of FeNO value in this population. We have shown that sex, age, height and atopic status by skin prick tests were determinants of FeNO.

Reference ranges for FeNO measured in accordance with the current ATS/ERS standards have been reported previously in children [11-13,17]. There were studies that assessed the reference equations of FeNO in healthy adults and, among these studies [14-18], only one involved healthy nonsmoking adults as in our study [14]. Many studies involved subjects who were current smokers or ex-smokers, with airway diseases or respiratory tract infections $[15,16,18,21,22]$. For example, a study from Germany included current smokers, asthma subjects and subjects with respiratory tract infections (in 24.3\%, 3.8\% and 20.2\%, respectively, among the 897 subjects) [15]. Other large-scale studies from Sweden [21] and Germany [18] measured FeNO values in $>2000$ and $>1000$ subjects, respectively. In these studies, subjects with physician-diagnosed asthma or those on inhaled steroids [21], or smokers or patients with 
TABLE 1 Demographics of the subjects

$\begin{array}{cc}\text { Median } & \text { SD } \\ \text { (interquartile range) }\end{array}$

\begin{tabular}{|c|c|c|c|}
\hline \multicolumn{4}{|l|}{ Age years } \\
\hline All & $47.3 \pm 16.6$ & $48(27.0)$ & $1093(100)$ \\
\hline $18-30$ & & & 216 (19.8) \\
\hline $31-40$ & & & 190 (17.4) \\
\hline $41-50$ & & & $188(17.2)$ \\
\hline $51-60$ & & & 208 (19.0) \\
\hline $61-70$ & & & 196 (17.9) \\
\hline $71-90$ & & & 95 (8.7) \\
\hline \multicolumn{4}{|l|}{ Sex } \\
\hline Male & & & $516(47.2)$ \\
\hline Female & & & $577(52.8)$ \\
\hline Height $\mathrm{cm}$ & $162.5 \pm 8.8$ & $163.0(13.0)$ & \\
\hline $\mathrm{BMI} \mathrm{kg} \cdot \mathrm{m}^{-2}$ & $24.0 \pm 3.7$ & $23.6(5.1)$ & \\
\hline \multicolumn{4}{|l|}{ Atopy } \\
\hline Positive & & & 645 (59.0) \\
\hline Negative & & & $444(40.6)$ \\
\hline Pre-bronchodilator FEV1 L & $2.76 \pm 0.77$ & $2.72(1.09)$ & \\
\hline Pre-bronchodilator FVC L & $3.12 \pm 0.85$ & $3.04(1.21)$ & \\
\hline Pre-bronchodilator FEV1/FVC ratio \% & $88.72 \pm 6.27$ & $89.29(7.39)$ & \\
\hline Pre-bronchodilator FEV1 \% predicted & $104.42 \pm 14.18$ & $104.72(122.29)$ & \\
\hline Pre-bronchodilator FVC \% predicted & $95.49 \pm 13.68$ & $96.15(94.61)$ & \\
\hline Post-bronchodilator FEV1 L & $2.82 \pm 0.77$ & $2.77(1.07)$ & \\
\hline Post-bronchodilator FVC L & $3.15 \pm 0.84$ & $3.06(1.19)$ & \\
\hline Post-bronchodilator FEV $1 /$ FVC ratio \% & $89.78 \pm 6.23$ & $90.19(7.61)$ & \\
\hline Post-bronchodilator FEV $1 \%$ predicted & $106.79 \pm 13.87$ & $107.15(123.65)$ & \\
\hline Post-bronchodilator FVC \% predicted & $96.57 \pm 13.04$ & $97.31(96.90)$ & \\
\hline Total IgE kIU $\cdot \mathrm{L}^{-1}$ & $151.6 \pm 393.4$ & $48.0(122.0)$ & \\
\hline Eosinophil count \% & $2.8+2.1$ & $2.0(3.0)$ & \\
\hline Eosinophil count $\times 10^{9} \cdot \mathrm{L}^{-1}$ & $0.188 \pm 0.196$ & $0.100(1.300)$ & \\
\hline
\end{tabular}

BMI: body mass index; FEV1: forced expiratory volume in $1 \mathrm{~s}$; FVC: forced vital capacity.

respiratory infections were included [18]. A very recent study from the USA reported the FeNO value in $>13000$ subjects aged 6-80 years [16]. This study involved children, adults, smokers, subjects with asthma and subjects on asthma medications. Subjects with self-reported asthma or wheezing, or who had prescriptions for asthma/wheezing in the past 12 months, were excluded when normal values and thresholds were calculated. Since the prediction model equations in this study were derived for age groups of $6-11$ years and $12-80$ years, teenagers $<18$ years of age were also included in the older age group [16].

When compared with the Caucasian population, adult Chinese subjects had a higher geometric mean FeNO value. Table 4 summarises the comparison of FeNO of normal adults without known lung diseases between different populations. Compared with the study performed in Sweden by OLIN et al. [14] with 1131 subjects,

TABLE 2 Multivariate linear regression of factors associated with fractional exhaled nitric oxide concentration (FeNO) value in healthy subjects

\begin{tabular}{|c|c|c|c|}
\hline & $\beta$ coefficients $(95 \% \mathrm{Cl})$ & Ratio of mean FeNo $(95 \% \mathrm{Cl})$ & p-value \\
\hline Sex & $0.085(0.044-0.127)$ & $1.216(1.107-1.340)$ & $<0.001$ \\
\hline Age per year & $0.004(0.003-0.005)$ & $1.009(1.007-1.012)$ & $<0.001$ \\
\hline Atopic status by skin test & $0.039(0.005-0.072)$ & $1.094(1.012-1.181)$ & 0.023 \\
\hline Height per $\mathrm{cm}$ & $0.003(0.001-0.005)$ & $1.007(1.002-1.012)$ & 0.014 \\
\hline Log IgE per kIU· $L^{-1}$ & $0.051(0.025-0.076)$ & $1.125(1.059-1.191)$ & $<0.001$ \\
\hline Eosinophil percentage per $\%$ & $0.016(0.009-0.023)$ & $1.038(1.021-1.054)$ & $<0.001$ \\
\hline
\end{tabular}

$\mathrm{n}=1093$. 
TABLE 3 95\% upper limits of fractional exhaled nitric oxide concentration ( $F$ eNo) (ppb) according to classes of height, age, sex and atopy calculated as mid-class values among 1093 healthy subjects

\begin{tabular}{|c|c|c|c|c|c|c|c|c|c|c|c|c|}
\hline & \multicolumn{12}{|c|}{ Age years } \\
\hline & \multicolumn{2}{|c|}{$18-30$} & \multicolumn{2}{|c|}{$31-40$} & \multicolumn{2}{|c|}{$41-50$} & \multicolumn{2}{|c|}{$51-60$} & \multicolumn{2}{|c|}{$61-70$} & \multicolumn{2}{|c|}{$71-90$} \\
\hline lale & & & & & & & & & & & & \\
\hline \multirow{2}{*}{\multicolumn{13}{|c|}{ Height $\mathrm{cm}$}} \\
\hline & & & & & & & & & & & & \\
\hline$<150$ & 28.5 & 23.5 & 31.9 & 26.3 & 34.9 & 28.8 & 38.3 & 31.6 & 40.0 & 34.7 & 48.3 & 39.9 \\
\hline $170-179.9$ & 34.3 & 28.3 & 38.4 & 31.7 & 42.1 & 34.7 & 46.2 & 38.1 & 50.6 & 41.8 & 58.2 & 48.0 \\
\hline$\geqslant 180$ & 36.5 & 30.1 & 40.8 & 33.7 & 44.8 & 36.9 & 49.1 & 40.5 & 53.9 & 44.5 & 61.9 & 51.1 \\
\hline \multicolumn{13}{|l|}{ Female } \\
\hline Atopy & + & - & + & - & + & - & + & - & + & - & + & - \\
\hline \multicolumn{13}{|l|}{ Height $\mathrm{cm}$} \\
\hline$<150$ & 22.5 & 18.5 & 25.1 & 20.7 & 27.5 & 22.7 & 30.2 & 24.9 & 33.1 & 27.3 & 38.0 & 31.4 \\
\hline$\geqslant 180$ & 28.8 & 23.7 & 32.1 & 26.5 & 35.3 & 29.1 & 38.7 & 31.9 & 42.4 & 35.0 & 48.7 & 40.2 \\
\hline
\end{tabular}

+: positive; -: negative.

our geometric mean FeNO was much higher (32.6 ppb versus $16.6 \mathrm{ppb}$ ). This ethnic difference was consistent with our previous observation in paediatric subjects involving 258 local and 33 Caucasian students with a mean age of 14 years in Hong Kong. We found that their mean FeNO was 25.3, 15.8, 14.9 and $10.1 \mathrm{ppb}$ for Chinese boys, Chinese girls, Caucasian boys and Caucasian girls, respectively [28]. Another large-scale paediatric study in Canada involving 656 school children aged 9-12 years also found that AsianCanadian subjects had a higher FeNO value than white subjects and the African-Canadian subjects [12]. Furthermore, a study involving 62 children in the UK found that FeNO was significantly higher, after correcting for atopic status, by an average of $36 \%$ in South Asians when compared to the white subjects [29]. A recent study from Taiwan involving 681 Asian children aged 5-18 years found that the geometric mean FeNO and the upper 95\% CI were 13.7 and 29.7 ppb, respectively, and this was also higher when compared with the Caucasian population [30]. In fact, other smaller-scale studies involving Chinese and Korean adults also showed a similar level of FeNO value to our study (table 4) [25-27]. A study involving 895 African-Americans noted that the mean FeNO for males and females were $27 \pm 26 \mathrm{ppb}$ and $18 \pm 18 \mathrm{ppb}$, respectively [31]. The FeNO value of this group of African-American subjects appeared to be greater than the Caucasian population but less than that of the Asian population. As this study involved asthma subjects and subjects with respiratory tract infection (current/past week), it is thus difficult to compare their results
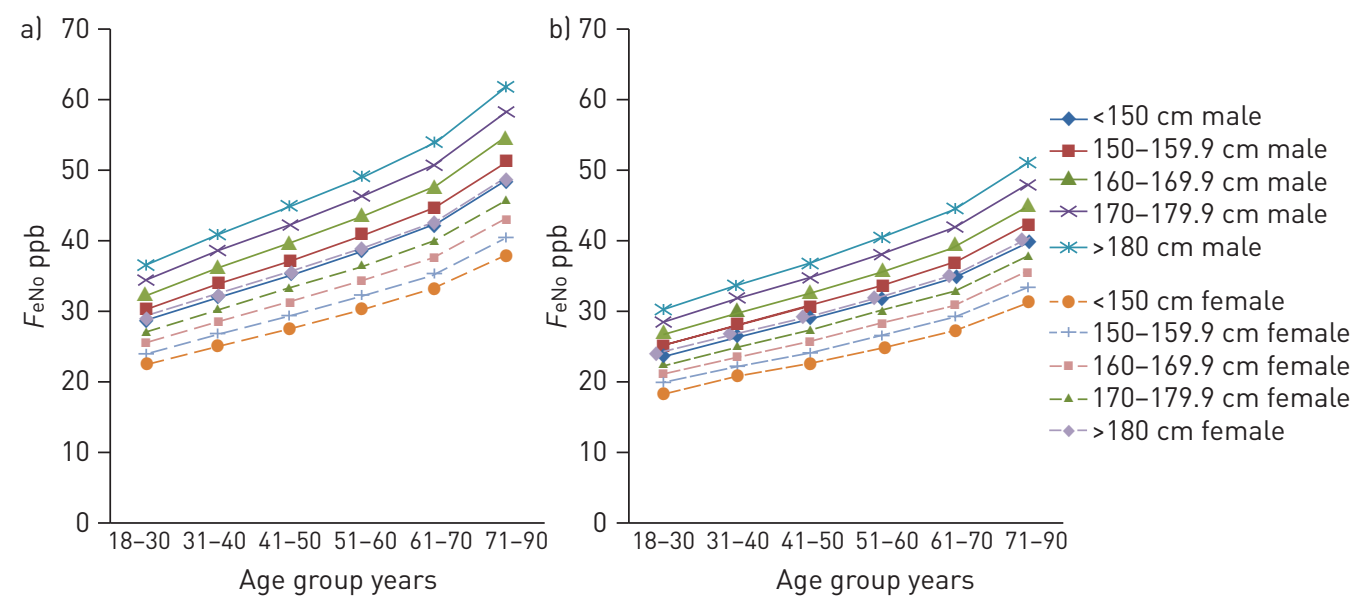

FIGURE 1 95\% upper limits of fractional exhaled nitric oxide concentration (FeNO) according to age and height in a) atopic subjects and $\mathrm{b}$ ) nonatopic subjects. 
TABLE 4 Comparison of fractional exhaled nitric oxide concentration ( $F$ eNo) in healthy adults in published studies

\begin{tabular}{|c|c|c|c|c|}
\hline Study & Year & Characteristics of the subjects & Instrument & Feno value \\
\hline TRAVERS et al. [23] & 2007 & $\begin{array}{l}\text { New Zealand } \\
n=193(93 \text { male and } 100 \text { female) } \\
\text { Age } 56.3 \pm 12.9 \text { years } \\
19(9.8 \%) \text { subjects were current } \\
\text { smokers } \\
46(23.8 \%) \text { subjects were atopic }\end{array}$ & $\begin{array}{l}\text { NIOX system; } \\
\text { Aerocrine AB, Solna, } \\
\text { Sweden }\end{array}$ & $\begin{array}{l}\text { Geometric mean } 17.9(90 \% \mathrm{Cl} 7.8-41.1) \mathrm{ppb} \text {, } \\
\text { without adjustment for sex, atopy and } \\
\text { smoking status }\end{array}$ \\
\hline OLIN et al. [14] & 2007 & $\begin{array}{l}\text { Sweden } \\
\mathrm{n}=1131 \text { ( } 558 \text { male, } 573 \text { female) } \\
\text { All never-smokers } \\
\text { Age } 50.3 \pm 13.81 \text { years } \\
286(25.3 \%) \text { had atopy }\end{array}$ & NIOX system & $\begin{array}{l}\text { Geometric mean } 16.6 \text { (95\% RI 5.87-47.14) ppb } \\
\text { for the whole population } \\
\text { Atopic subjects } 18.8 \text { ( } 95 \% \mathrm{RI} 6.03-58.74) \mathrm{ppb} \\
\text { nonatopic subjects } 16.0 \text { (95\% RI } \\
5.91-58.76) \mathrm{ppb} \\
\text { Males } 18.5 \text { (95\% RI 16.67-51.13) ppb; females } \\
14.9 \text { (95\% RI 5.36-41.52) ppb }\end{array}$ \\
\hline CHNG et al. [25] & 2005 & $\begin{array}{l}\text { Singapore } \\
45 \text { normal subjects ( } 34 \text { with atopy and } \\
11 \text { with no atopy) } \\
\text { Sex distribution not stated } \\
\text { Mean (range) age } 19.6 \text { (18-27) years } \\
\text { Smoking status unknown }\end{array}$ & NIOX system & $\begin{array}{l}\text { Median (range) } 38.4(16.7-49.3) \mathrm{ppb} \text { for atopic } \\
\text { subjects; } 15.7(11.5-21.7) \mathrm{ppb} \text { for nonatopic } \\
\text { subjects }\end{array}$ \\
\hline KıM et al. [26] & 2010 & $\begin{array}{l}\text { Korea } \\
\mathrm{n}=166 \text { ( } 80 \text { male and } 86 \text { female) } \\
80(48.1 \%) \text { subjects had atopy } \\
\text { Age } 33.2 \pm 12.1 \text { years and } \\
32.2 \pm 7.9 \text { years for males and } \\
\text { females, respectively (range } \\
20-86 \text { years) } \\
\text { All non-smokers }\end{array}$ & $\begin{array}{l}\text { NO analyser } 280 i \\
\text { Sievers Instruments, } \\
\text { Boulder, CO, USA }\end{array}$ & $\begin{array}{l}\text { Mean FeNO of male and female subjects were } \\
35.7 \pm 13.2 \mathrm{ppb} \text { and } 26.0 \pm 14.2 \mathrm{ppb} \text {, } \\
\text { respectively } \\
\text { Mean FeNO of atopic males } 37.3 \pm 12.1 \mathrm{ppb} \text {; } \\
\text { nonatopic males } 33.9 \pm 14.3 \mathrm{ppb} \text {; atopic } \\
\text { females } 28.6 \pm 17.7 \mathrm{ppb} \text {; and nonatopic } \\
\text { females } 24.1 \pm 10.6 \mathrm{ppb}\end{array}$ \\
\hline
\end{tabular}

Data are presented as mean $\pm S D$, unless otherwise stated. Only publications involving healthy adults with no known respiratory disease were selected. All instruments used a flow rate of flow rate of $50 \mathrm{~mL} \cdot \mathrm{s}^{-1}$.

directly with "healthy" subjects of other populations or ethnicity [31]. Another large US study involving Hispanic, white, black and subjects of other ethnicities also found that using white subjects as reference, other ethnic groups had higher FeNO value. However, the composition of the other ethnic groups was unspecified in this study [16]. There is also some smaller-scale study of FeNO value in normal healthy subjects of other populations [32].

Our study found that male subjects had a higher FeNO value than female subjects and atopy was associated with higher FeNO value. In addition, height and age were both positively associated with the FeNO level. Furthermore, these factors all had independent association with the FeNO value as multivariate analysis with adjustment of the other factors found a statistically significant association. Age and height were important factors for FeNO in children $[12,13]$. The effect of age and height affecting FeNO in adults is less 
consistent, with studies showing conflicting results $[14,15]$. Concerning the effect of sex on FeNO, our study noted a major difference between sexes, similar to the results reported by Travers et al. [23] and TAYLOR et al. [33]. However, this was not observed in the study by OlIN et al. [14]. There is also a controversial relationship between FeNO and atopy. Some studies have suggested that atopy, such as the number of positive skin prick tests and total IgE level, may affect FeNO value [34, 35], whereas other studies suggested that FeNO value was not influenced by atopy [36]. Concerning the upper limit of normal of the FeNO value, our study found that the upper limits of FeNO value ranged from 19 to $62 \mathrm{ppb}$, depending on age, sex, height and atopic status. There was only one study that assessed the FeNO value in a large population of healthy adults, and that found that the upper limits of FeNO ranged from 24.0 to $54.0 \mathrm{ppb}$, depending on age, height and atopy [14]. When comparing this Swedish study with our study, apart from the difference in ethnicity, their subjects were older, taller and had less atopy. Difference in body build and height can affect lung volume and this may also account for the variations of FeNO value among different populations.

Apart from the demographic factors of the subjects (such as age and ethnicity), other factors may also affect FeNO level. A previous study found that exhaled NO measurements in healthy subjects and patients with airways disease differed according to the type of analyser used [37]. Their study compared three brands of machines (Ecomedics (Dürnten, Switzerland), NIOX (Aerocrine AB, Solna, Sweden) and Logan Research Ltd (Rochester, UK)). Sievers, the brand of machine used in this study, was not assessed. It was thus not certain whether the difference in the FeNO level in our population when compared to other studies would be attributable to machine difference. This factor might not be very significant as all current machines should follow the ATS/ERS guidelines [2,3] for calibration and maintenance. Conversely, a study from Singapore using the NIOX machine in testing 45 first-year Asian medical students and another study from Korea involving 166 adults aged 20-80 years using the same Sievers machine as in this study [26], found similar FeNO values to our study [25].

We speculated that differences in environmental exposures or genetic polymorphisms of high-producing nitric oxide synthase genotypes would be related to the FeNO level in different populations. The production of endogenous nitric oxide from L-arginine is dependent on the enzyme NO synthase (NOS). All NOS isoenzymes convert L-arginine to L-citrulline, with the generation of NO. Three isoforms of NOS are known. NOS1 and NOS3 are both constitutively expressed in the human airway, whereas NOS2 is inducible by inflammation [38]. It is possible that differences in genetic background may affect the activity of NOS enzymes resulting in differences in NO production. A population-based study of young adult twins revealed that variation in FeNO was explained by genetic and nonshared environmental effects [39]. A previous study noted that the NOS3 missense sequence variant in the endothelial NOS gene (G894T) was associated with FeNO in an American cohort of subjects with asthma. The TT genotype had a significantly higher FeNO than the GT genotype [40]. An inhibitor of iNOS was noted to produce marked inhibition of FeNO in both normal and asthmatic subjects [41]. Further studies are needed to assess the genetic contributions of $\mathrm{FeNO}$ value in different ethnicities. Apart from genetic factors, environmental factors such as air pollution, allergens and diet may also affect the FeNO level, but we have not assessed these factors in this study [42-45].

This study had some limitations. FeNO was measured on just one occasion for the subjects and repeatability was not tested. In addition, we recruited volunteers to join the study and the subjects were not randomly recruited from a large population or community. The percentage of atopic subjects in this study was on the high side and this might be due to selection bias.

In summary, we have shown that sex, age, atopic status and height were determinants of FeNO value in a large population of Chinese subjects. FeNO value in the Chinese subjects appeared to be higher than that of the Caucasian population. In this population, the upper limits of FeNO ranged from 19 to $62 \mathrm{ppb}$, depending on their age, sex, height and atopic status. Further studies are needed to explore the genetic and other determinants of FeNO. This study provides useful population-based reference values for the accurate interpretation of FeNO levels in the Chinese population.

\section{References}

1 Barnes PJ, Dweik RA, Gelb AF, et al. Exhaled nitric oxide in pulmonary diseases: a comprehensive review. Chest 2010; 138: 682-692.

2 American Thoracic Society, European Respiratory Society. ATS/ERS recommendations for standardized procedures for the online and offline measurement of exhaled lower respiratory nitric oxide and nasal nitric oxide, 2005. Am J Respir Crit Care Med 2005; 171: 912-930.

3 Dweik RA, Boggs PB, Erzurum SC, et al. An official ATS clinical practice guideline: interpretation of exhaled nitric oxide levels (FeNO) for clinical applications. Am J Respir Crit Care Med 2011; 184: 602-615.

4 Alving K, Weitzberg E, Lundberg JM. Increased amount of nitric oxide in exhaled air of asthmatics. Eur Respir J 1993; 6: 1368-1370. 
Jatakanon A, Lim S, Chung KF, et al. An inhaled steroid improves markers of airway inflammation in patients with mild asthma. Eur Respir J 1998; 12: 1084-1088.

6 Strunk RC, Szefler SJ, Phillips BR, et al. Relationship of exhaled nitric oxide to clinical and inflammatory markers of persistent asthma in children. J Allergy Clin Immunol 2003; 112: 883-892.

7 Steerenberg PA, Janssen NA, de Meer G, et al. Relationship between exhaled NO, respiratory symptoms, lung function, bronchial hyperresponsiveness, and blood eosinophilia in school children. Thorax 2003; 58: 242-245.

8 Smith AD, Cowan JO, Filsell S, et al. Diagnosing asthma: comparisons between exhaled nitric oxide measurements and conventional tests. Am J Respir Crit Care Med 2004; 169: 473-478.

9 Dupont LJ, Demedts MG, Verleden GM. Prospective evaluation of the validity of exhaled nitric oxide for the diagnosis of asthma. Chest 2003; 123: 751-756.

10 Petsky HL, Cates CJ, Li AM, et al. Tailored interventions based on exhaled nitric oxide versus clinical symptoms for asthma in children and adults. Cochrane Database Syst Rev 2008; 2: CD006340.

11 Baraldi E, Azzolin NM, Cracco A, et al. Reference values of exhaled nitric oxide for healthy children 6-15 years old. Pediatr Pulmonol 1999; 27: 54-58.

12 Kovesi T, Kulka R, Dales R. Exhaled nitric oxide concentration is affected by age, height, and race in healthy 9- to 12-year-old children. Chest 2008; 133: 169-175.

13 Buchvald F, Baraldi E, Carraro S, et al. Measurements of exhaled nitric oxide in healthy subjects age 4 to 17 years. J Allergy Clin Immunol 2005; 115: 1130-1136.

14 Olin AC, Bake B, Torén K. Fraction of exhaled nitric oxide at $50 \mathrm{~mL} / \mathrm{s}$ : reference values for adult lifelong neversmokers. Chest 2007; 131: 1852-1856.

15 Dressel H, de la Motte D, Reichert J, et al. Exhaled nitric oxide: independent effects of atopy, smoking, respiratory tract infection, gender and height. Respir Med 2008; 102: 962-969.

16 See KC, Christiani DC. Normal values and thresholds for the clinical interpretation of exhaled nitric oxide levels in the US general population: results from the National Health and nutritional examination survey 2007-2010. Chest 2013; 143: 107-116.

17 Jacinto T, Alving K, Correia R, et al. Setting reference values for exhaled nitric oxide: a systematic review. Clin Respir J 2012 [in press DOI: 10.1111/j.1752-699X.2012.00309.x].

18 Karrasch S, Ernst K, Behr J, et al. Exhaled nitric oxide and influencing factors in a random population sample. Respir Med 2011; 105: 713-718.

19 Standardization of spirometry - 1987 update. Statement of the American Thoracic Society. Am Rev Respir Dis 1987; 136: 1285-1298.

20 Pepys J. Skin tests. Br J Hospital Med 1975; 14: 412-417.

21 Olin AC, Rosengren A, Thelle DS, et al. Height, age, and atopy are associated with fraction of exhaled nitric oxide in a large adult general population sample. Chest 2006; 130: 1319-1325.

22 van Asch CJ, Balemans WA, Rovers MM, et al. Atopic disease and exhaled nitric oxide in an unselected population of young adults. Ann Allergy Asthma Immunol 2008; 100: 59-65.

23 Travers J, Marsh S, Aldington S, et al. Reference ranges for exhaled nitric oxide derived from a random community survey of adults. Am J Respir Crit Care Med 2007; 176: 238-242.

24 Olivieri M, Talamini G, Corradi M, et al. Reference values for exhaled nitric oxide (reveno) study. Respir Res 2006; 7: 94.

25 Chng SY, Van Bever HP, Lian D, et al. Relationship between exhaled nitric oxide and atopy in Asian young adults. Respirology 2005; 10: 40-45.

26 Kim SH, Kim TH, Sohn JW, et al. Reference values and determinants of exhaled nitric oxide in healthy Korean adults. J Asthma 2010; 47: 563-567.

27 Tsang KW, Ip SK, Leung R, et al. Exhaled nitric oxide: the effects of age, gender and body size. Lung 2001; 179: 83-91.

28 Wong GW, Liu EK, Leung TF, et al. High levels and gender difference of exhaled nitric oxide in Chinese schoolchildren. Clin Exp Allergy 2005; 35: 889-893.

29 Sonnappa S, Bastardo CM, Stafler P, et al. Ethnic differences in fraction of exhaled nitric oxide and lung function in healthy young children. Chest 2011; 140: 1325-1331.

30 Yao TC, Lee WI, Ou LS, et al. Reference values of exhaled nitric oxide in healthy Asian children aged 5 to 18 years. Eur Respir J 2012; 39: 378-384.

31 Levesque MC, Hauswirth DW, Mervin-Blake S, et al. Determinants of exhaled nitric oxide levels in healthy, nonsmoking African American adults. J Allergy Clin Immunol 2008; 121: 396-402.

32 Habib SS, Abba AA, Al-Zoghaibi MA, et al. Reference range values of fractional exhaled nitric oxide in healthy Arab adult males. Saudi Med J 2009; 30: 1395-1400.

33 Taylor DR, Mandhane P, Greene JM, et al. Factors affecting exhaled nitric oxide measurements: the effect of sex. Respir Res 2007; 8: 82.

34 Cardinale F, de Benedictis FM, Muggeo V, et al. Exhaled nitric oxide, total serum IgE and allergic sensitization in childhood asthma and allergic rhinitis. Pediatr Allergy Immunol 2005; 16: 236-242.

35 Brussee JE, Smit HA, Kerkhof M, et al. Exhaled nitric oxide in 4-year-old children: relationship with asthma and atopy. Eur Respir J 2005; 25: 455-461.

36 Latzin P, Beck J, Griese M. Exhaled nitric oxide in healthy children: variability and a lack of correlation with atopy. Pediatr Allergy Immunol 2002; 13: 37-46.

37 Borrill Z, Clough D, Truman N, et al. A comparison of exhaled nitric oxide measurements performed using three different analysers. Respir Med 2006; 100: 1392-1396.

38 Barnes PJ. NO or no NO in asthma? Thorax 1996; 51: 218-220.

39 Lund MB, Kongerud J, Nystad W, et al. Genetic and environmental effects on exhaled nitric oxide and airway responsiveness in a population-based sample of twins. Eur Respir J 2007; 29: 292-298.

40 Storm van's Gravesande K, Wechsler ME, Grasemann H, et al. Association of a missense mutation in the NOS3 gene with exhaled nitric oxide levels. Am J Respir Crit Care Med 2003; 168: 228-231.

41 Hansel TT, Kharitonov SA, Donnelly LE, et al. A selective inhibitor of inducible nitric oxide synthase inhibits exhaled breath nitric oxide in healthy volunteers and asthmatics. FASEB J 2003; 17: 1298-1300. 
42 Berhane K, Zhang Y, Linn WS, et al. The effect of ambient air pollution on exhaled nitric oxide in the Children's Health Study. Eur Respir J 2011; 37: 1029-1036.

43 Graveland H, Van Roosbroeck SA, Rensen WM, et al. Air pollution and exhaled nitric oxide in Dutch schoolchildren. Occup Environ Med 2011; 68: 551-556.

44 Olin AC, Aldenbratt A, Ekman A, et al. Increased nitric oxide in exhaled air after intake of a nitrate-rich meal. Respir Med 2001; 95: 153-158.

45 Rosenkranz SK, Townsend DK, Steffens SE, et al. Effects of a high-fat meal on pulmonary function in healthy subjects. Eur J Appl Physiol 2010; 109: 499-506. 